
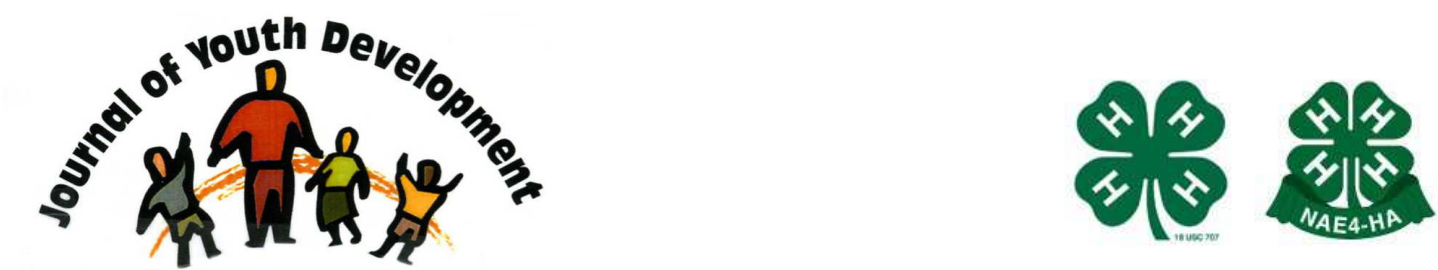

Bridging Research \& Practice

\title{
4-H \& FFA Livestock Projects: Life Skills Gained and Knowledge Learned
}

Lyle N. Holmgren

Utah State University

Brigham City, Utah

lyleh@ext.usu.edu

Chad R. Reid

Utah State University

Cedar City, Utah

chadr@ext.usu.edu 


\title{
JOURNAL OF YOUTH DEVELOPMENT \\ bridging research and practice

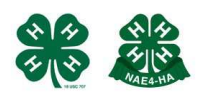

Volume 2, Number 1, Summer 2007

Article 0701RS002

\section{4-H \& FFA Livestock Projects: Life Skills Gained and Knowledge Learned}

\author{
Lyle N. Holmgren and Chad R. Reid \\ Utah State University
}

\begin{abstract}
Junior Livestock shows are one of the most popular 4- $\mathrm{H}$ and FFA projects in Utah. Thousands of youth participate in these shows from every county in Utah. County extension agents and FFA advisors spend much time with livestock committees, leaders, parents, and youth engaged in livestock shows. Can public funds spent on salaries be justified for county 4-H extension agents and FFA advisors who work with junior livestock shows? To help answer this question, 413 youth involved in livestock shows in Utah were surveyed in 2001. Youth were asked to share skills learned from their livestock projects. Value statements along with specific content skills were measured in the survey. The results indicate that from their 4-H and FFA projects, youth learned to accept responsibility, follow instructions, gain self-confidence, follow instructions, "do the right thing" as well as a variety of other values and content skills.
\end{abstract}

\section{Introduction}

Junior Livestock shows provide a unique educational experience for youth development. Ward (1996) provided evidence that 4-H and FFA animal science programs benefit youth by helping them develop valuable life skills. In Utah, youth who participate in 4-H begin livestock projects as early as $3^{\text {rd }}$ grade and can continue until the summer after they graduate from high school. Boleman, Cummings and Biers (2004) noted that parents of 4- $\mathrm{H}$ and FFA youth indicated that the longer children actively engage in the project, the more likely they are to develop life skills that will hopefully make them more productive as adults. They also confirmed that positive life skills in youth are enhanced as a result of participation in 4-H and FFA livestock projects. Many of these youth begin learning positive life skills, including responsibility, at an early age. Some 
research suggests that as 4-H and FFA programming intervenes in a youth's life, irresponsible behavior can be avoided (Boyd, Herring, and Briers, 1992).

\section{Purpose and Objectives}

County 4-H extension agents, 4-H workers and FFA advisors spend considerable time working with livestock committees, leaders, parents, and youth. Can public and private funds spent on youth with livestock projects be justified?

Studies related to the impact of 4-H livestock projects on the development of life skills are well documented. In one study conducted by Boleman, Cummings, \& Briers (2004), parents were asked to address the life skill development of their children participating in 4-H livestock projects. In another study, Ward (1996) explored evidence that 4-H alumni attribute the development of important life skills to their participation in animal science projects.

This research focuses on the following objectives:

1. What values and life skills are youth developing as a result of their 4-H or FFA livestock project?

2. What 4-H and FFA projects other than livestock and horse projects are youth enrolled in?

3. What are 4-H and FFA youth learning as a result of their livestock projects?

Its purpose is to access the value of these projects for youth development as well as help extension educators and FFA advisors identify opportunities to develop quality programs for youth with livestock projects.

\section{Methodology}

A survey was developed that asked youth to share what they learned as a result of their livestock projects. Value statements along with specific content skills were measured in the survey. The survey was used to collect data from two groups of youth involved in two separate livestock shows in 2001. One group surveyed $1314-\mathrm{H}$ and FFA youth attending the Southwest Junior Livestock Show (SWJL) in Cedar City, Utah, a Utah Department of Agriculture and Food (UDAF) sponsored livestock show and the other sampled $2824-\mathrm{H}$ and FFA youth who participated in the Box Elder County Junior Livestock Show (BEJL) in Tremonton, Utah, a county sponsored show.

Youth who participate in 4-H and FFA livestock projects come from a wide range of residential backgrounds. Almost two-thirds of youth (63\%) declared they reside in non-production farm residences. Many live in small towns or in rural non-farm areas. Of 131 youth that responded at the SWJL show, 57.5\% were male and $42.5 \%$ were female. Youth from 17 Utah counties participated in the SWJL show. At the BEJL show 282 youth responded and of that total, $47.4 \%$ were male and $52.6 \%$ were female. In the combined livestock shows, $66.3 \%$ of the respondents had been involved in $4-\mathrm{H}$ less than 4 years. 
Table 1

Residence During 4-H Project

\begin{tabular}{|l|c|c|}
\hline & $\%$ & N \\
\hline Town under 50,000 population & 16 & 66 \\
\hline Rural non-farm & 17 & 70 \\
\hline Hobby Farm (under 5 acres) & 30 & 124 \\
\hline Production Farm (over 5 acres) & 37 & 153 \\
\hline Total & 100 & 413 \\
\hline
\end{tabular}

\section{Findings}

The survey asked youth to identify impacts from participating in livestock projects. Value statements along with specific content skills were measured. As a result of their 4-H and FFA livestock project, some values and skills were learned or reinforced significantly by participation. On the other hand, there are some values and skills that youth did not learn as well. For example, in Table 4, more than $97 \%$ of youth who participated in these two junior livestock shows report that they are very confident showing an animal at a junior livestock show. On the other hand only $35 \%$ of these youth have explored careers in agriculture.

\section{Values and Life Skills Gained}

Twenty-one life skills were analyzed individually to reveal mean values and standard deviations (Table 2). These life skills were based on research conducted by Lee, Beard and Straquadine (2003) and the 4-H Youth Survey of the National 4-H Impact Assessment Project conducted by Peterson, et al (2000). Youth were asked what they learned as a result of their livestock project. The rank order for the top five mean scores was: "to accept responsibility for doing a job" $(4.48, \mathrm{SD}=0.63)$, followed by "to value the contributions of others" $(4.48, \mathrm{SD}=0.68)$, "to be friends with people who are different than me" $(4.45, \mathrm{SD}=0.66)$, "to follow instructions as they are given to me" $(4.41, \mathrm{SD}=0.63)$, and " to understand what was required to have a successful livestock or horse project" $(4.39, \mathrm{SD}=0.70)$. 
Table 2

Life Skills Gained

(listed in descending order by mean)

\begin{tabular}{|c|c|c|c|}
\hline & $\mathbf{N}$ & Mean & SD \\
\hline to accept responsibility for doing a job & 415 & 4.48 & 0.63 \\
\hline to value the contributions of others & 414 & 4.48 & 0.68 \\
\hline to be friends with people who are different than me & 393 & 4.45 & 0.66 \\
\hline to follow instructions as they are given to me & 415 & 4.41 & 0.63 \\
\hline $\begin{array}{l}\text { to understand what was required to have a successful livestock } \\
\text { or horse project }\end{array}$ & 414 & 4.39 & 0.70 \\
\hline how to make decisions & 414 & 4.35 & 0.72 \\
\hline how to help others & 413 & 4.34 & 0.66 \\
\hline to use time and money efficiently & 415 & 4.33 & 0.77 \\
\hline how to gain confidence in myself & 415 & 4.33 & 0.71 \\
\hline to not use illegal drugs or alcohol & 414 & 4.33 & 1.04 \\
\hline to set goals & 413 & 4.32 & 0.71 \\
\hline the value and importance of ethics "doing the right thing" & 412 & 4.32 & 0.77 \\
\hline that I have some control over events in my life & 413 & 4.26 & 0.75 \\
\hline $\begin{array}{l}\text { to feel comfortable saying "no" to things that I do } \\
\text { not want to do. }\end{array}$ & 412 & 4.21 & 0.88 \\
\hline to help others reach their goals & 413 & 4.20 & 0.78 \\
\hline to accept opinions different from mine & 413 & 4.17 & 0.67 \\
\hline how to keep records & 411 & 4.16 & 0.83 \\
\hline to live a healthy lifestyle & 414 & 4.14 & 0.89 \\
\hline to solve problems that occur in my life & 412 & 4.14 & 0.83 \\
\hline to want to tell my friends to enroll in a livestock/horse project. & 415 & 4.05 & 0.93 \\
\hline to meet and work with people of other cultures & 413 & 3.94 & 0.85 \\
\hline
\end{tabular}

Scale: 5 = Strongly Agree, 4 = Agree, 3 = Neutral, 2 = Disagree, 1 = Strongly Disagree

The high ranking of "to accept responsibility for doing a job" is consistent with Boleman, Cummings and Briers (2004) research for life skill development of youth participating in 4-H beef projects from a parent's perception. These findings are also consistent with Ward's (1996) research of life skill development of youth who participate in animal science projects. It is interesting that both youth and parents perceive accepting responsibility as the number one life skill gained from a livestock project. 
In general, 4- $\mathrm{H}$ and FFA members agree or strongly agree that as a result of their 4- $\mathrm{H}$ and FFA livestock project they learned responsibility, leadership, communication, positive interactions with other youth and adults, and personal development skills. Although the average response for not using illegal drugs or alcohol was high (4.33 on a 5 point scale), the standard deviation suggests more variability in the answers to that question and indicates some respondents might be more likely to use illegal drugs or alcohol.

\section{4-H and FFA Participation in Activities and Projects}

Youth who participate in 4-H clubs have a wide range of projects they can choose from. Many positive life skills are formulated by participation in structured 4-H clubs and through hands on learning. For example, Astroth (1996) found that 4-H clubs can be effective at helping youth develop critical life skills such as decision-making, responsibility, interpersonal skills, how to get along with others and an ethic of service. Astroth \& Haynes (2002) later found that 4-H effectively develops life skills. His research showed 4-H members are more likely than non 4-H members to be able to make their own decisions, do things on their own, set goals, try new things, and take responsibility for their actions. This research supports the findings of Astroth and others. 4-H and FFA livestock projects effectively help youth develop critical life skills such as accepting responsibility, getting along with others, setting goals, decision making and interpersonal skills. In addition, youth in this survey report following instructions, money management, saying "no" to things they do not want to do, and gaining confidence as attributes derived from their 4-H or FFA livestock projects.

Table 3

Activities 4-H and FFA Youth Have Participated In (ranked in ascending order)

\begin{tabular}{|l|c|c|c|c|}
\hline & & & & $\begin{array}{c}\text { Mean } \\
\mathbf{1}=\mathbf{Y} \\
\mathbf{2 =}\end{array}$ \\
\hline Officer training & $\mathbf{N}$ & Yes & No \\
\hline Science and technology & 397 & $5.5 \%$ & $94.5 \%$ & 1.94 \\
\hline Communications & 396 & $8.1 \%$ & $92.0 \%$ & 1.92 \\
\hline Committee member & 397 & $10.1 \%$ & $90.0 \%$ & 1.90 \\
\hline Demonstrations & 397 & $12.3 \%$ & $87.7 \%$ & 1.88 \\
\hline State contests & 397 & $17.1 \%$ & $82.9 \%$ & 1.83 \\
\hline Held club office & 397 & $23.2 \%$ & $76.8 \%$ & 1.77 \\
\hline Leadership & 397 & $22.7 \%$ & $77.3 \%$ & 1.77 \\
\hline Community service & 397 & $25.4 \%$ & $74.6 \%$ & 1.75 \\
\hline Portfolio/record book & 397 & $36.0 \%$ & $64.0 \%$ & 1.64 \\
\hline & 397 & $44.8 \%$ & $55.2 \%$ & 1.55 \\
\hline
\end{tabular}

Penn State (2004) researchers have found that most youth are involved in the implementation aspect of 4-H projects but have minimal input in the planning and evaluation components of the process. Seevers and Dormody (2000) reported that adults who work with 4-H programs may 
not be providing youth the opportunity to be involved in the total leadership process including planning, implementing and evaluating.

The rank in ascending order of the bottom five activity areas 4- $\mathrm{H}$ and FFA youth participate in from Table 3 are: "officer training" (5.5\% Yes), "science and technology" (8.1\% Yes), "communications" (10.1\% Yes), "committee member" (12.3\% Yes), "demonstrations" (17.1\% Yes).

This survey's relatively low rankings for questions related to receiving officer training, science and technology, communications, being a committee member and conducting a demonstration show that 4-H and FFA programs should be developed and modified so that more leadership, science and technology and communication opportunities are available to 4-H and FFA youth with livestock projects.

\section{Knowledge Youth Learned From Their Projects}

Ward (1996) found that specific events in 4-H animal science programs appear to have a positive influence on the development of important life skills. Most notable are such activities as livestock shows and livestock judging activities. The top five skills youth learned from their 4-H project ranked in order are "show an animal" (97.01\% Yes), "care for an animal" (96.77\% Yes), "feed an animal" (95.77\% Yes), "groom an animal" (95.77\% Yes) and "keep an animal healthy" $(91.79 \%$ Yes). Areas where youth did not feel they learned as much from their $4-\mathrm{H}$ or FFA project are "giving oral reasons" (33.33\% Yes), "learning about careers in agriculture" (35.15\% Yes).

Table 4

Knowledge Learned From Their Projects

(ranked in descending order)

\begin{tabular}{|l|c|c|c|c|}
\hline & & & & $\begin{array}{c}\text { Mean } \\
\mathbf{1 =} \text { Yes } \\
\mathbf{2 =} \text { No }\end{array}$ \\
\hline Show an animal & N & Yes & No & 1.03 \\
\hline Care for an animal & 402 & $97.01 \%$ & $2.99 \%$ & 1.03 \\
\hline Feed an animal & 402 & $96.77 \%$ & $3.23 \%$ & 1.04 \\
\hline Groom an animal & 402 & $95.77 \%$ & $4.23 \%$ & 1.04 \\
\hline Keep an animal healthy & 402 & $95.77 \%$ & $4.23 \%$ & 1.08 \\
\hline Select an animal & 402 & $91.79 \%$ & $8.21 \%$ & 1.14 \\
\hline Determine the cost to raise an animal & 400 & $86.00 \%$ & $14.00 \%$ & 1.15 \\
\hline Practice safety around animals & 402 & $84.58 \%$ & $15.42 \%$ & 1.24 \\
\hline Understand animal reproduction & 402 & $76.12 \%$ & $23.88 \%$ & 1.51 \\
\hline Learn about careers & 402 & $48.51 \%$ & $51.49 \%$ & 1.65 \\
\hline Give oral reasons & 404 & $35.15 \%$ & $64.85 \%$ & 1.67 \\
\hline
\end{tabular}




\section{Conclusions}

4-H and FFA livestock projects provide an excellent opportunity for youth to develop valuable positive life skills that will benefit them as they become adults. Accepting responsibility for doing a job is paramount for these youth and is well documented in similar research. Caring for an animal project requires responsibility and fortitude. The study noted that youth seem to be comfortable with grooming, feeding, showing and caring for their animal project but are not as comfortable or knowledgeable with the principles of animal reproduction, understanding products produced from livestock or career opportunities in agriculture.

Although it is widely documented that 4-H and FFA can effectively develop life skills in its members, the results of this survey show that many youth who have livestock projects either do not have the opportunity to participate in other 4-H activities outside the realm of livestock or horse projects or simply choose not to participate. Many youth do not have the opportunity to sit on committees. Most have not held a club office or received training on how to be an officer in their club. These youth could benefit from exploring 4-H projects such as leadership, science and technology and communication. Locally, youth need opportunities to participate as committee members and as leaders in their 4-H club. For example, older FFA youth could gain leadership experience leading a club of young 4-H'ers.

Our findings indicated that emphasis should be placed on leadership and communication development by encouraging youth to be members of county 4-H and FFA livestock and horse committees, junior club leaders, etc. State-wide and county extension programming might be reevaluated for educational events like demonstrations, leadership training and state contests to attract youth with livestock projects.

This study demonstrates the value of surveys in determining what youth development skills are strengthened by participating in youth livestock projects. Youth development professionals could conduct similar surveys to determine the value of other projects they are promoting.

\section{References}

Astroth, K.A. (1996). Leadership in Nonformal Youth Groups: Does Style Affect Youth Outcomes? Journal of Extension [Online], 34(6). Available at:

http://www.joe.org/joe/1996december/rb2.html

Astroth, K.A., Haynes, G.W. (2002). More Than Cows \& Cooking: Newest Research Shows the Impact of 4-H. Journal of Extension [Online], 40(4). Available at:

http://www.joe.org/joe/2002august/a6.shtml

Boleman, C.T., Cummings, S.R., Briers, G.E. (2004). Parents' Perceptions of Life Skills Gained by Youth Participating in the 4-H Beef Project. Journal of Extension [Online], 42(5). Available at: http://www.joe.org/joe/2004october/rb6.shtml

Boyd, B.L., Herring, D.R., Briers, G.E. (1992). Developing Life Skills in Youth. Journal of Extension [Online], 30(4). Available at: http://www.joe.org/joe/1992winter/a4.html 
Lee, C.D, Beard, R., Straquadine, G.S. (2003). Description of Utah 4-H Club Members' Perceived Level of Critical Elements in the 4-H Experience. Proceedings of the 22nd Annual Western Region Agricultural Education Research Conference. Available at: http://oregonstate.edu/dept/ag-ed/wrae/proceedings/papers/Lee,Beard,Straquadine.pdf

Penn State. (2004). Leadership Development of Youth and Adults Involved with FFA \& 4-H Programs, Research Project Outline \#3887. Available at: http://research.cas.psu.edu/projects/PEN03887.pdf

Peterson, B., Gerhard, G., Hunter, K., Marek, L., Phillips, C., Titcomb, A. (2000). National 4-H impact Assessment Project. Perspectives from a Nationwide Survey, National 4-H.

Available at: http://www.national4-hheadquarters.gov/about/impact/impact1.pdf

Seevers, B.S. and Dormody, T.J. (2000). 4-H Youth Participation in Leadership Development Activities: A Tri-State Study. Journal of Agricultural Education, 35(4) 49-54.

Available at: http://pubs.aged.tamu.edu/jae/pdf/Vol35/35-04-49.pdf

Ward, C.K. (1996). Life Skill Development Related to Participation in 4-H Animal Science Projects. Journal of Extension [Online], 34(2). Available at:

http://www.joe.org/joe/1996april/rb2.html

(C) Copyright of Journal of Youth Development Bridging Research and Practice. Content may not be copied or emailed to multiple sites or posted to a listserv without copyright holder's express written permission. However, users may print, download or email articles for individual use. 